\title{
Bestuurlijke transities in de rooms-katholieke kerk
}

Henk Witte

In de laatmoderne samenleving vindt een aantal ingrijpende bestuurlijke transities plaats in de rooms-katholieke kerk. ${ }^{1}$ In Nederland en omringende landen is de reorganisatie van het parochiestelsel wellicht het meest opvallende verschijnsel. Maar dit is beslist niet de enige bestuurlijke verandering in deze kerk. In deze bijdrage wil $i k$ twee bestuurlijke overgangen uitdrukkelijk naar voren halen. De eerste betreft de toename van het bestuurlijk gewicht van de bisschop en het bisdom, bestuurlijk gezien het middenniveau in de rooms-katholieke kerk. Een tweede overgang betreft het model waarin deze kerk over haar organisatie denkt. Vanouds is dat een verenigingsmodel. Het maakt echter gaandeweg - en onder invloed van de digitalisering van het samenleven versneld - plaats voor een netwerkmodel.

Beide ontwikkelingen kunnen worden begrepen vanuit het religieuze moderniseringsparadigma, zoals dat ontwikkeld is door de godsdienstsocioloog Staf Hellemans. ${ }^{2}$ Naast sociaal-culturele processen en factoren zijn echter ook theologische overwegingen en beslissingen in het spel. Ik begin met een korte introductie van het door Hellemans ontwikkelde theoretisch kader. Vervolgens ga ik in op het toenemend belang van een bestuurlijk middenniveau. Daarna schets ik een aantal bestuurlijke transities als gevolg van de invloed van de digitalisering. Zij brengen belangrijke uitdagingen met zich mee voor de kerkelijke leiding en haar beleid. Die uitdagingen vormen het laatste aandachtspunt.

\section{Van 'ultramontaans massakatholicisme' naar 'keuzekatholicisme'}

Hellemans benadert sociale ontwikkelingen op het gebied van de religie vanuit het religieuze moderniseringsparadigma. Deze manier van benaderen let op de wisselwerking tussen ontwikkelingen op maatschappelijk vlak en op religieuskerkelijk vlak. Religieuze ontwikkelingen vinden immers in een maatschappelijke bedding plaats. ${ }^{3}$ Ze worden erdoor beïnvloed, zoals ze ook van hun kant een impact hebben op het samenleven. Als de samenleving modern wordt, gebeurt dat met religie en kerk evenzeer.

1 Met dank aan Staf Hellemans voor zijn feedback.

2 S. Hellemans, Het tijdperk van de wereldreligies. Religie in agrarische civilisaties en in moderne samenlevingen, Zoetermeer/Kapellen 2007; S. Hellemans, 'A Critical Transition. From Ultramontane Mass Catholicism to Choice Catholicism', in: P.C. Beentjes (red.), The Catholic Church and Modernity in Europe (Tilburg Theological Studies 3), Münster 2009, p. 32-54; S. Hellemans, 'Tracking the New Shape of the Catholic Church in the West', in: S. Hellemans \& J. Wissink (red.), Towards a New Catholic Church in Advanced Modernity. Transformations, Visions, Tensions (Tilburg Theological Studies 5), Münster 2012, p. 19-50.

3 Hellemans 2007 p. 32-35; Hellemans 2009, p. 35-36; Hellemans 2012, p. 20. 
$\mathrm{Na}$ een overgangsperiode, meestal vol crisisverschijnselen en onrust, tekent zich zowel maatschappelijk als kerkelijk een bepaalde formatie af die gedurende langere tijd voor stabiliteit zorgt. Met het oog op de kerk spreekt Hellemans van 'kerkformaties'. De meest recente transitie vindt plaats tussen wat hij noemt 'ultramontaans massakatholicisme' en 'keuzekatholicisme'.

Het ultramontaans massakatholicisme kan worden beschouwd als de kerkformatie uit de negentiende en de eerste helft van de twintigste eeuw. ${ }^{4}$ Het begin ervan valt samen met het begin van de industrialisering en de sociale gevolgen daarvan, zoals migratie en verstedelijking.

Kenmerkend van deze kerkformatie is volgens Hellemans allereerst een vergaande centralisatie van de kerkelijke organisatie. De ogen van alle gelovigen waren gericht op de paus (ultramontanisme). Deze bevestigde en versterkte zijn gezag met een stroom van toespraken en encyclieken. Het Eerste Vaticaans Concilie (1869-1870) onderschreef zijn gezagvolle positie in lerend en bestuurlijk opzicht met de afkondiging van de dogma's van de pauselijke onfeilbaarheid en van het pauselijk jurisdictieprimaat. Op zich lijkt de tendens tot centraal besturen een katholiek streven van alle tijden, al moet daarbij worden aangetekend dat eerst sinds de gregoriaanse hervorming in de elfde eeuw de pausen proactief de kerk gingen leiden in plaats van een veeleer volgende opstelling ten opzichte van het leiderschap van keizers en vorsten in het eerste millennium. ${ }^{5}$ Een tweede kenmerk van het ultramontaans massakatholicisme betreft het streven om de gelovigen en masse te bereiken en van dag tot dag te activeren, te mobiliseren en te disciplineren. In dit perspectief staan het bekende 'van de wieg tot het graf' en de hoge mate waarin en intensiteit waarmee het katholieke verenigingsleven tot ontwikkeling kwam. Dit alles leidde - een derde kenmerk - tot de vorming van een besloten submaatschappij met een eigen subcultuur die zich duidelijk onderscheidde van en afzette tegen andere subgroepen en hun culturen.

Vanaf ongeveer 1960 verliest het ultramontaans massakatholicisme aan krediet en begint zich een nieuwe kerkformatie te ontwikkelen. Hellemans typeert haar als 'keuzekatholicisme'. ${ }^{6}$ Het is de kerkformatie die laatmoderne sociaal-culturele ontwikkelingen zoals een toenemende individualisering en groeiend pluralisme weerspiegelt. De term 'keuzekatholicisme' wijst op de noodzaak van het kiezen in het laatmoderne samenleven. Het is een indicatie van de toegenomen autonomie van het individu en diens streven naar authenticiteit. Groepsvorming, ook in religieus en kerkelijk opzicht, gaat steeds meer steunen op een bewuste keuze van autonome individuen. 'Opgelegde groepen', zoals de godsdienstsociologe Liliane Voyé ze noemt, ${ }^{7}$ - zij bedoelt daarmee groepen waaraan een individu zich nauwelijks kan onttrekken - vormen steeds minder de sociale basis van een religieus of kerkelijk engagement. Hellemans ziet als gevolg daarvan een kerk tot ontwikkeling komen die maatschappelijk een minderheidspositie heeft. Zij zal zowel naar

$4 \quad$ Hellemans 2007, p. 186-194; Hellemans 2009, p. 37-39; Hellemans 2012, p. 21-23.

$5 \quad$ P. Raedts, De uitvinding van de rooms-katholieke kerk, Amsterdam 2014.

$6 \quad$ Hellemans 2007 p. 186-194; Hellemans 2009, p. 39-41; Hellemans 2012, p. 23-37.

7 L. Voyé, 'Het kerkinstituut uitgedaagd', in: J. Stevens e.a., Geloven in de kerk. Een multidisciplinaire benadering, Averbode 2000, p. 85-92. 
buiten als intern moeten afzien van machtsstrategieën: autonoom geworden gelovigen maken immers eigen keuzen. Organisatorisch zal zij zich flexibel moeten opstellen: de desintegratie van het parochiestelsel en de toenemende bestuurlijke invloed van intermediaire bestuurlijke niveaus zijn er uitingen van. ${ }^{8}$ Verder verwacht Hellemans dat in de kerkformatie van het keuzekatholicisme de ervaringsdimensie van geloven, spiritualiteit en kerkelijke gemeenschapsvorming in belang zal toenemen, ${ }^{9}$ dat de kerken worden terugverwezen naar hun religieuze kerntaak en niet langer als instituties zullen functioneren die alle levensgebieden overkoepelen, en dat de rooms-katholieke kerk steeds meer een wereldkerk zal blijken met inbreng en invloed uit alle continenten en een grote variëteit aan contexten. Dit laatste brengt met zich mee dat een westerse c.q. Europese dominantie in die kerk de eigen relativiteit moet leren inzien en ermee moet leren omgaan. De keuze van paus Franciscus als eerste niet-Europeaan tot paus is een uiting ervan.

\section{Het toenemend belang van een kerkelijk middenniveau}

Structureel gezien kent de rooms-katholieke kerk drie 'bestuurslagen': de universele kerk (of wereldkerk), het bisdom (in het katholiek taaleigen 'plaatselijke kerk' of 'lokale kerk' geheten, in documenten vaak ook aangeduid als 'particuliere kerk' - ecclesia particularis) en de parochie. ${ }^{10}$ 'Bestuurslaag' is misschien iets te profaan gesteld voor deze niveaus van kerk-zijn, hoewel deze structuur ook kerkjuridisch is vastgelegd. Het doorslaggevende motief van de driedeling is echter niet bestuurlijke efficiëntie of iets soortgelijks. Het is theologisch van aard. Op elk van deze niveaus is de kerk namelijk ten volle kerk in de theologische zin van het woord. Dat betekent dat de drie basisfuncties van het kerk-zijn - verkondigen, vieren en 'herderen' (in de zin van leiding aan de gemeenschap en aan individuele gelovigen of 'zielen' in de vorm van pastoraat en diaconie) - op elk van die niveaus tot hun recht komen. Het betekent bovendien dat elk niveau beschikt over een eigen en wettig aangestelde ambtsdrager: de paus, een bisschop, een pastoor. Typerend voor de kerkelijkheid in theologische zin van deze drie niveaus van kerk-zijn is dat gelovigen er op zondag samenkomen om de eucharistie, de bron en het hoogtepunt van het kerkelijk leven, te vieren.

De verhouding tussen universele kerk en plaatselijke kerk is iets anders dan die tussen bisdom en parochie. In het geval van de universele kerk en de plaatselijke kerk is er sprake van wederzijdse doordringing of perichorese, zoals men in de theologie graag zegt met een term ontleend aan de verhouding tussen de godde-

8 W. Damberg \& S. Hellemans (red.), Die neue Mitte der Kirche. Der Aufstieg der intermediären Instanzen in den europäischen Großkirchen seit 1945 (Konfession und Gesellschaft 42), Stuttgart 2010; vgl. Hellemans 2012, p. 28-32.

9 Zie ook S. Hellemans, 'Spiritualiteit en mystiek in de katholieke Kerk', in: S. Hellemans, J. van den Eijnden \& P. Rentinck (red.), Een katholieke Kerk met toekomst (afscheidsbundel J. Wissink), Bergambacht 2012, p. 85-95.

10 H. Witte, 'Die katholische Kirche in den Niederlanden. Wandlungsprozesse nach dem Zweiten Vatikanischen Konzil', in: W. Damberg \& S. Hellemans (red.), Die neue Mitte der Kirche. Der Aufstieg der intermediären Instanzen in den europäischen Großkirchen seit 1945 (Konfession und Gesellschaft 42), Stuttgart 2010, p. 139-142. 
lijke personen in de triniteit. De universele kerk bestaat in en uit plaatselijke kerken, zoals ook plaatselijke kerken bestaan in en uit de universele kerk. Er is weliswaar discussie over de vraag of daarbinnen prioriteit toekomt aan de universele kerk, zoals de brief Communionis notio van de Congregatie van de Geloofsleer van 28 mei 1992 stelt. ${ }^{11}$ Onder paus Benedictus XVI, in zijn vorige functie als prefect van de Congregatie voor de Geloofsleer eerste ondertekenaar van de brief, werd deze prioriteit ook bestuurlijk benadrukt. Paus Franciscus lijkt te zoeken naar een beter evenwicht tussen universele kerk en lokale kerken. 'Het past niet dat de Paus de plaats van de plaatselijke bisschoppen inneemt in het onderscheiden van alle problemen die zich in hun gebied voordoen', schrijft hij in de apostolische exhortatie Evangelii Gaudium van 24 november 2013. 'In deze zin ben ik mij bewust van de noodzaak om een gezonde 'decentralisatie' te bevorderen. ${ }^{12}$ Dit besef is wellicht mede ingegeven door de jezuïtische achtergrond van de paus. In die traditie immers leeft een sterk besef van de noodzaak om zich aan te passen aan tijd, plaats, omstandigheden en personen en daarmee ook van de eigen verantwoordelijkheid van degenen die in andere contexten werkzaam zijn. ${ }^{13}$

In het geval van de verhouding tussen bisdom en parochie is er sprake van een geheel-deel-relatie. Het Wetboek van Kerkelijk Recht spreekt over de parochie als 'een bepaalde gemeenschap van christengelovigen, in een particuliere Kerk duurzaam opgericht, waarover de herderlijke zorg, onder het gezag van de diocesane Bisschop, aan een pastoor als haar eigen herder is toevertrouwd'. ${ }^{14}$ Een parochie is primair een gemeenschap en als zodanig een pars van een diocees. ${ }^{15} \mathrm{Ze}$ is meestal maar niet noodzakelijk (bijvoorbeeld als de ritus, taal of nationaliteit van gelovigen daarom vragen) territoriaal begrensd. ${ }^{16}$

De rooms-katholieke kerk kent naast deze drieledige structuur ook twee bestuurlijk georiënteerde tusseninstanties: de bisschoppenconferentie tussen universele en lokale kerken en het dekenaat tussen bisdom en parochies. Kenmerkend voor deze tussenliggende instanties is dat het hulpstructuren zijn. Zij dienen te bevorderen dat de kerk in een bepaald gebied haar taken goed kan uitoefenen. Maar zij zijn geen kerk in de theologisch volle zin van het woord. Dat blijkt ook uit het feit dat zij niet op zondag samenkomen om eucharistie te vieren. Zij zijn dan ook gericht op het welzijn (bene esse) van de kerk, niet op het kerk-zijn (esse) zelf. Bestuurlijk impliceert het dat zij aangewezen zijn op samenwerking en consensusvorming van de units die zij overkoepelen.

11 Congregation for the Doctrine of the Faith, Letter to the Bishops of the Catholic Church on some aspects of the Church as Communion - Communionis notio, zie www. vatican.va/ roman_curia/ congregations/cfaith/documents/rc_con_cfaith_doc_28051992_communionis-notio_en.html.

12 Paus Franciscus, Evangelii Gaudium. Apostolic Exhortation on the Proclamation of the Gospel in Today's World, nr. 16, zie / www. vatican. va/ content/ francesco/ en/ apost_exhortations/ documents/papa-francesco_esortazione-ap_20131124_evangelii-gaudium.html.

13 S. Schloesser, 'Accomodation as a Rhetorical Principle. Twenty Years after John W. O’Malley's The First Jesuits (1993)', Journal of Jesuit Studies 2014, p. 347-372.

14 CIC canon $515, \S 1$.

15 CIC canon $374, \S 1$.

16 CIC canon 518. 
De positie als hulpstructuur impliceert dat een bisschoppenconferentie theologisch en juridisch geen grotere zeggingsmacht heeft dan een diocesane bisschop. Integendeel, de zeggingsmacht van een diocesane bisschop is groter. Dat is vastgelegd in het motu proprio Apostolos suos van 21 mei 1998 van paus Johannes Paulus II, ${ }^{17}$ nadat de buitengewone bisschoppensynode van 1985 gevraagd had deze kwestie op te helderen. Het motief van de sterkere positie van de diocesane bisschop is primair theologisch van aard: hij is immers qualitate qua lid van het bisschoppencollege van de universele kerk. Bovendien is de samenwerking van een aantal bisschoppen in een bepaald gebied mede bepaald door historische omstandigheden. Dat geeft aan de samenstelling van een bisschoppenconferentie iets toevalligs. Zij kan gemakkelijk veranderen en mist de stabiliteit die een universeel verband suggereert. De wederkerige doordringing van universele kerk en lokale kerken - of in termen van leiderschap: de collegialiteit van paus en bisschoppen - is kerkjuridisch en theologisch daarom van meer gewicht dan de samenwerking van een aantal bisschoppen in een bepaald gebied in een bisschoppenconferentie. De collegialiteit van paus en bisschoppen wordt dan ook 'effectief' genoemd, die van een aantal bisschoppen met elkaar heet 'affectief.

Iets analoogs is het geval in de verhouding tussen een deken en een pastoor. Ook een deken is bestuurlijk en coördinerend aangewezen op de welwillendheid en bereidheid tot samenwerken van pastoors. Dat alles maakt tusseninstanties als bisschoppenconferenties en dekenaten tot zwakke instituties. Bij beleidsmatige tegenwind of financiële dan wel personele krimpsituaties zullen ze dan ook worden afgezwakt, in aantal verminderd of zelfs opgeheven.

In de kerkformatie van het ultramontaans massakatholicisme was er sprake van een vrijwel directe invloed van 'Rome' op de parochie. Het diocesane middenniveau stelde bestuurlijk niet veel voor. Een bisschop had vooral een administratieve taak, aangevuld met enkele speciale ceremonieel-liturgische bevoegdheden, zoals de bediening van de sacramenten van het vormsel en van de wijding. Een bisschop zag zichzelf als doorgeefluik van beslissingen en besluiten van 'Rome'. Ook zijn bestuurlijk apparaat was gering. Volgens de Naamlijst van de R.K. Geestelijkheid van het bisdom 's-Hertogenbosch van 15 december 1958 bestond de staf van het bisdom uit acht personen: de bisschop, de bisschop-coadjutor, de vicarisgeneraal en vijf secretariële medewerkers, onder wie een econoom en een archivaris. Verder waren nog zeven personen op diocesaan niveau actief als aalmoezenier van de diverse standsorganisaties. Veel diocesane functies echter werden in de vorm van een nevenfunctie vervuld door clerici met een andere hoofdtaak. Zo was de president van het grootseminarie tegelijkertijd officiaal van de kerkelijke rechtbank.

Dat veranderde in de periode na het Tweede Vaticaans Concilie (1962-1965). Het bestuurlijk gewicht van het middenniveau in de kerk nam aanzienlijk toe, althans voor zover het een kerkelijke ambtsdrager als bestuurder heeft en niet buiten diens directe zeggingsmacht valt, zoals in het geval van orden en congregaties of 
door leken bestuurde katholieke maatschappelijke organisaties. ${ }^{18}$ De gewichtstoename van het bestuurlijk middenniveau bleek onder meer uit de uitbreiding van de staven van bisdommen, de oprichting en uitbouw van diocesane dienstverleningscentra en de toename van het diocesane takenpakket. Ook op kerkprovinciaal en dekenaal niveau groeide de omvang van ondersteunende diensten. Dat ging door tot zich een financiële krimpsituatie begon voor te doen. Die leidde tot inkrimping of afbouw van in eerste instantie diensten op kerkprovinciaal en dekenaal niveau ${ }^{19}$ en meer recent ook van het ondersteunend apparaat van de leiding van bisdommen.

Op de achtergrond van deze transitie spelen deels maatschappelijke, deels kerkelijke en deels theologische factoren. Maatschappelijk gezien kan worden gewezen op de toegenomen complexiteit van het laatmoderne samenleven. Een goede omgang daarmee ter plaatse vraagt om expertise. Die expertise bevindt zich op een bovenplaatselijk niveau. Te denken valt aan deskundigheid op het gebied van bouw en onderhoud van gebouwen, civiele wet- en regelgeving, contacten met andere kerken of landelijk georganiseerde sectoren zoals het katholieke onderwijs en het steeds belangrijkere terrein van de media en de moderne communicatiemiddelen.

Kerkelijk gezien zijn meerdere factoren in het spel. In de eerste 25 jaar na het Tweede Vaticaans Concilie zal de implementatie van de vernieuwingsimpulsen van dit concilie de kerkelijke beleidsagenda bepalen. Vanaf 1990 komt daarbij de bewustmaking van het feit dat de kerk in een West-Europese context een missionaire opdracht heeft. Verder vindt er een uitbreiding plaats van het diocesane takenpakket en vraagt de herstructurering van het parochiestelsel de nodige aandacht van het diocesane middenniveau. De invoering van de vernieuwingen van het Tweede Vaticaans Concilie vroeg om een catechetisch en pastoraal vormingsaanbod ten dienste van het gemeenschapsleven ter plaatse. Het werd dekenaal of diocesaan georganiseerd en vaak ook op dat niveau aangeboden. Vooral leken, die steeds meer een actieve taak in de parochies op zich namen, maakten ervan gebruik. Als na 1990 het besef toeneemt dat ook Nederland zozeer ontkerkelijkt dat het een missieland is geworden en nieuwe evangelisatie wenselijk is, nemen de bisdommen het voortouw ten aanzien van de bewustmaking hiervan en de inhoudelijke concretisering van deze opdracht. De uitbreiding van het takenpakket van de bisdommen had te maken met twee, overigens niet geheel van elkaar te scheiden factoren: enerzijds de verschraling van de draagkracht van de parochie om haar taken naar behoren uit te voeren of bepaalde doelgroepen te bereiken; anderzijds het streven om nieuwe doelgroepen te bereiken en nieuwe vormen van kerkelijk samenkomen te ontwikkelen. Het jongerenpastoraat, de roepingenpastoraal en de organisatie van bijeenkomsten in het kader van de Wereldjongerendagen zijn er voorbeelden van. ${ }^{20}$ Het spreekt voor zich dat ingrij-

18 W. Damberg \& S. Hellemans, 'Die Neugestaltung der europäischen Großkirchen und der Aufstieg der intermediären Instanzen seit 1945/1960', in: W. Damberg \& S. Hellemans (red.), Die neue Mitte der Kirche. Der Aufstieg der intermediären Instanzen in den europäischen Großkirchen seit 1945 (Konfession und Gesellschaft 42), Stuttgart 2010, p. 225.

19 Voor Nederland, zie Witte 2010, p. 149-152 en 153-156.

20 Vgl. Damberg \& Hellemans 2010, p. 222-223. 
pende processen als de herstructurering van het parochiestelsel om sturing en begeleiding vanuit een diocesaan niveau vroegen en vragen.

Naast deze maatschappelijke en kerkelijke factoren speelt ook een theologische factor een rol van betekenis. Ik zou die factor willen typeren als een theologische statusverhoging van het bisschopsambt. In de eerste plaats worden de diocesane bisschoppen in beginsel meer dan voordien het geval was, betrokken in het bestuur van de universele kerk. Als 'zichtbaar beginsel en fundament van de eenheid in hun particuliere kerken' vormen zij samen met de paus als hoofd één college, zoals het Tweede Vaticaans Concilie stelt. ${ }^{21}$ In de tweede plaats onderstreept het concilie dat de bisschopswijding een sacramenteel karakter heeft en dat het bisschopsambt daarmee de hoogste graad van het wijdingssacrament is. ${ }^{22}$ Vanouds was de priester de voornaamste identificatiefiguur met betrekking tot het ambt in de katholieke kerk. Zijn voornaamste taak en bevoegdheid immers betrof het voorgaan in de eucharistie of - in een oudere terminologie - het 'opdragen van het Heilig Misoffer'. Zijn taak betrof dan ook direct het 'ware lichaam van Christus' (corpus Christi verum). Het bisschopsambt werd primair als een waardigheid (dignitas) beschouwd. Een bisschop had enkele extra kerkjuridische bevoegdheden om de priesterlijke taak in de parochies mogelijk te maken. Zo was alleen een bisschop bevoegd om priesters, een kerkgebouw, het altaar of het heilig vaatwerk te wijden. Hij was dan ook primair gericht op de kerk, verstaan als 'mystiek lichaam van Christus' (corpus Christi mysticum), en slechts indirect op de eucharistie. ${ }^{23}$ Door de sacramentaliteit van het bisschopsambt te bevestigen schiep het Tweede Vaticaans Concilie de voorwaarden dat de figuur van de bisschop zich kon ontwikkelen tot de belangrijkste identificatiefiguur van het kerkelijk ambt. Bijgevolg werd ook de verhouding tussen een bisschop en diocesane priesters anders. Typerend is de benadering van de priesters als 'ijverige medewerkers van de Orde der Bisschoppen'. ${ }^{24}$ De theologische statusverhoging van het bisschopsambt correspondeert met de toename van het belang van het diocesane middenniveau in bestuurlijk opzicht.

Een historische terugblik in grote lijnen laat zien dat reeds in de vroegmoderne tijd de bisschop op zijn bestuurlijke taak werd gewezen. ${ }^{25}$ Het Concilie van Trente (1545-1563) wees op zijn residentie- en visitatieplicht en maande hem zo aan bestuurlijk actief te worden in zijn diocees. Volgens Damberg en Hellemans is dit een eerste signaal van het toenemend belang van een kerkelijk middenniveau in bestuurlijk opzicht. Het kreeg volgens hen echter eerst goed vorm in de negentiende eeuw, toen in een ultramontaans klimaat de kerkelijke organisatie werd

21 Dogmatische constitutie over de Kerk Lumen gentium, nr. 22-23. Over de rol van kardinaal Alfrink in de conciliaire discussie over de bisschoppelijke collegialiteit, zie H. Witte, 'Kerk besturen: oud en nieuw naast elkaar', in: Van Nijkerk tot wereldkerk. Symposium, Utrecht 2000, p. 3-8.

22 Lumen gentium, nr. 21.

23 W. Kasper, Die Kirche und ihre Ämter. Schriften zur Ekklesiologie II, Freiburg/Basel/Wien 2009, p. 471.

24 Lumen gentium, nr. 28. Zie M. Fallert, Mitarbeiter der Bischöfe. Das Zueinander des bischöflichen und priesterlichen Amtes auf und nach dem Zweiten Vatikanischen Konzil, Würzburg 2007, p. 8-200. Damberg \& Hellemans 2010, p. 234-238. 
uitgebouwd. ${ }^{26}$ Dat gebeurde aanvankelijk met een monarchaal accent, toegespitst op de rol van de paus. Het Tweede Vaticaans Concilie versterkte de rol van de diocesane bisschoppen. Het juxtapositionele karakter van de katholieke vernieuwingsstrategie - 'oud' en 'nieuw' naast elkaar - brengt weliswaar een ambivalentie met zich mee op het vlak van de concrete vormgeving aan hun rol. ${ }^{27}$ Niettemin impliceert de sterkere betrokkenheid van de diocesane bisschoppen in de leiding van de universele kerk, juist vanwege hun leiderschap over lokale kerken, dat binnenkerkelijke pluraliteit in beginsel sterker in het besturen van de kerk betrokken kan worden en dat een decentrale inbreng op centraal niveau kan worden ingebracht. In dat opzicht past deze ontwikkeling in de groei naar de kerkformatie van het keuzekatholicisme. Het beleidsmatig oog op diocesaan niveau voor het bereiken van verschillende doelgroepen bevestigt deze trend. Kerkelijk besturen kan niet langer om de pluralisering en de individualisering - welbeschouwd is individualisering pluralisering in extremis - heen.

\section{Op weg naar een digitale wereld}

Dat brengt ons bij een tweede laatmoderne ontwikkeling met grote impact op het bestuurlijk functioneren van de rooms-katholieke kerk: de toenemende invloed van de digitalisering van de leefwereld en het samenleven.

Volgens de cultuurfilosoof René Munnik is de digitalisering een maatschappelijke ontwikkeling op basis van een technologische vinding. ${ }^{28}$ Hoewel de technische kant ervan gebaseerd is op voorzienbare natuurwetenschappelijke processen, blijkt de reikwijdte onvoorspelbaar. Dat is volgens hem een eerste kenmerk van een technologische ontwikkeling. Een tweede hangt ermee samen: het verschijnsel van wat hij met de techniekfilosoof Lewis Mumford 'pseudomorfie' noemt. Het wijst op het gegeven dat nieuwe technologie wordt waargenomen in het kader van het oude vertrouwde en in dat licht als 'verbetering' wordt gewaardeerd, terwijl het eigene ervan over het hoofd wordt gezien. Munnik geeft als voorbeeld de ontwikkeling van de eerste automobiel. Dat deze "koets-zonderpaard' de ontwikkeling van het wegennet en de petrochemische industrie met zich mee zou brengen, werd niet gezien. Verdere kenmerken van technologische ontwikkelingen zijn dat ze op een gegeven moment onzichtbaar worden, omdat wij ze 'gewoon' zijn gaan vinden, en dat ze een bemiddelende functie hebben in de ontsluiting van diverse aspecten van de werkelijkheid. Zo kwam in de zestiende

26 Voor ecclesiologische achtergronden, zie H. Witte, “"Ecclesia, quid dicis de teipsa?” Can ecclesiology be of any help to the Church to deal with advanced modernity?', in: S. Hellemans \& J. Wissink (red.), Towards a New Catholic Church in Advanced Modernity. Transformations, Visions, Tensions (Tilburg Theological Studies 5), Münster 2012, p. 123-134; M.J. Lacey, 'Leo's Church and Our Own', in: M.J. Lacey \& F. Oakley (red.), The Crisis of Authority in Catholic Modernity, Oxford/New York 2011, p. 57-92.

27 H. Witte, 'Reform with the Help of Juxtapositions. A Challenge to the Interpretation of the Documents of Vatican II', The Jurist 2011, p. 20-34.

28 R. Munnik, 'De digitalisering van de wereld', Collationes 2014, p. 5-22, hier 6-11. Zie ook van dezelfde auteur Tijdmachines. Over de technische onderwerping van vergankelijkheid en duur, Zoetermeer 2013. 
eeuw de horlogemaker model te staan voor God als schepper en wordt thans in computertermen gedacht over de werking van het brein.

Als technologische ontwikkeling lijkt de digitalisering de plaats te gaan innemen van een eerdere invloedrijke technologische vinding: het alfabet. Die vinding heeft grote invloed gehad op de religie, de cultuur en het recht, aldus Munnik. Zij bracht op schrift gebaseerde religies voort, een op geletterdheid gebaseerde cultuur - met onder meer oog voor geschiedschrijving en voor reflexief denken - en een op codificatie berustende rechtspleging. ${ }^{29}$ Thans grijpt een omvangrijk proces van informatisering om zich heen. Er begint zich een cultuur te ontwikkelen die gebaseerd is op digitalisering. Wat kenmerkend ervan zal zijn, moet grotendeels nog blijken. De groeiende invloed van beelden als drager van informatie en communicatie lijkt een aspect ervan.

De vraag is nu welke impact de digitalisering van de leefwereld op het besturen van de kerk heeft. Mijns inziens heeft zij een katalyserend effect op de individualisering, vooral in de zin van zelfbeschikking en autonomie. Die heeft op haar beurt tot gevolg dat het model van een vereniging of een staat, waarin de roomskatholieke kerk over haar organisatie en sociale gestalte dacht, gaandeweg op gespannen voet komt te staan met het model van een netwerkorganisatie zoals dat zich in een digitaliserende wereld ontwikkelt. ${ }^{30}$

Mediadeskundigen zijn het erover eens dat het internet horizontaliteit in de communicatie tussen mensen bevordert. Volgens Hans Geybels zijn de nieuwe media, althans in het gebruik, democratisch gestructureerd en gevoelig voor inspraak en medezeggenschap. Hij vindt dat vooral binnenkerkelijk een grote uitdaging. Een 'uni-laterale, hiërarchisch gestuurde vorm van top-downcommunicatie sluit niet langer aan bij een samenleving die democratischer gestructureerd is. (...) De huidige ontvangers van boodschappen gaan actief om met die boodschappen en spelen ten volle hun rol als creatieve participanten aan kerk en samenleving. ${ }^{31}$

Mijns inziens gaat de verschuiving ten gevolge van de digitalisering verder dan een vraag om meer inbreng of medezeggenschap, met andere woorden: om deelgenootschap in het centrum van de zeggenschap of macht. Een digitaliserende wereld is immers een polycentrische wereld. Achter een computer of met een iPhone in de hand weet eenieder zich een autonoom centrum van communicatie. Ik kan zelf en onafhankelijk van tijd en plaats bepalen met wie ik contact opneem, wanneer en hoe lang, welke boodschappen ik tot mij laat doordringen en welke niet, en hoe ik erop reageer. Zeker, deze autonomie is relatief. De techniek moet immers goed werken en de programmatuur moet betrouwbaar zijn. Mijn autonomie is, anders gezegd, afhankelijk van de macht van giganten als Apple, Microsoft en Google. Dat neemt niet weg dat ik mij op het moment van het gebruik zelf ervaar als een autonoom centrum van macht. Dat geldt voor iedere gebruiker. Een digitale wereld kent vele centra van zulke macht. Het is een polycentrische wereld.

30 In het volgende werk ik enkele eerder verschenen gedachten; zie $\mathrm{H}$. Witte, 'Ecclesiologische kanttekeningen op de digitale omwenteling', Collationes 2014, p. 73-86.

31 H. Geybels, 'Theologie van de communicatie', Collationes 2014, p. 49. 
Dit polycentrisme stelt de rooms-katholieke kerk bestuurlijk voor een grote uitdaging. Zij was immers in de kerkformatie van het ultramontaans massakatholicisme gewend bestuurlijk vanuit één centrum te denken en te opereren. Dat paste in het concept waarin de rooms-katholieke kerk in die tijd over haar sociale gestalte dacht. Tot aan de Eerste Wereldoorlog gebeurde dat vrijwel uitsluitend - in termen van societas perfecta - naar het model van de staat, nadien ook in het model van de vereniging.

De benadering van de sociale gestalte van de kerk als een staat heeft middeleeuwse wortels in de aristotelisch-thomistische staatsfilosofie. Die zag de staat als een natuurlijke gemeenschap (societas naturalis), onafhankelijk van een hogere instantie met gezag en daarom juridisch en feitelijk toegerust om tegemoet te komen aan de behoeften van de mensen. Vandaar dat een staat beschouwd werd als een societas perfecta en societas completa. ${ }^{32}$ Dit concept werd ook op de kerk toegepast, zij het dat zij in tegenstelling tot de staat niet alleen het tijdelijk welzijn van mensen als doelstelling had, maar ook het hogere doel van hun eeuwig heil. In de negentiende eeuw bereikt het denken over de gestalte van de kerk in staatstermen een hoogtepunt. In de eerste plaats zette de rooms-katholieke kerk zich daarmee af tegen het protestantse (vooral lutherse) Staatskirchentum, dat de organisatie van de kerk aan de wereldlijke overheid had toevertrouwd en over binnenkerkelijke gemeenschapsvorming dacht in termen van een groeps- of collegevorming op vrijwillige basis - een systeem dat bekend staat als het Kollegialsystem. ${ }^{33}$ In katholieke ogen was de kerk echter geen vrijwillig samengaan van gelovigen, als het ware 'van onderaf', maar een initiatief van Godswege. Deze overtuiging verklaart ook de katholieke weerstand tegen een contrat socialdenken. In de negentiende en vroege twintigste eeuw komt daarbij de conflictueuze verhouding tussen de rooms-katholieke kerk en de natiestaten die zich in Europa beginnen te vormen. De Kulturkampf in Duitsland, de ontmanteling van de kerkelijke staat in Italië en de kerkvervolging in Frankrijk rond de eeuwwisseling waren er uitingen van. Met behulp van het model van de societas perfecta benadrukte de kerk niet alleen haar juridische onafhankelijkheid ten opzichte van de staat, het gaf haar ook termen in handen om haar superioriteit tegenover de staat te articuleren. De kerk was immers door Jezus Christus gesticht. Haar oorsprong, inrichting en doelbepaling gingen daarom terug op de wil van God zelf. Men veronderstelde daarbij een tamelijk eenvoudig staatsconcept. De staat werd beschouwd als een zelfstandige gemeenschap van mensen met een leiding. Ook die leiding was van Godswege ingesteld. Dat maakte de kerk intern tot een gemeenschap van ongelijken, een societas inaequalis, een gemeenschap waarin sommigen, in feite de clerus, het voor het zeggen hadden over de anderen.

Als de grootste spanningen tussen kerk en staat na de Eerste Wereldoorlog geluwd zijn, komt er ook ruimte om over de sociale gestalte van de kerk na te denken in verenigingstermen, zonder dat dit refereert aan een protestantse kerkstructuur. Een sprekend voorbeeld staat in een Nederlands catechetisch hand-

32 J. Listl, Kirche und Staat in der neueren katholischen Kirchenrechtswissenschaft (Staatskirchenrechtliche Abhandlungen Bd. 7), Berlijn 1978, p. 107-112. Zie ook Witte 2012, p. 124-128. 
boekje uit het interbellum. Het definieert de kerk als een vereniging door Christus gesticht. Het legt eerst in een algemeen gangbare termen uit wat een vereniging is. 'Een vereeniging is in het algemeen: een verzameling van menschen, die allen hetzelfde doel hebben en door een bepaald gezag of bestuur geleid, samenwerken, om dat doel te bereiken. ${ }^{34}$ Die omschrijving wordt vervolgens op de kerk betrokken. Daarbij is het doel nader ingevuld als het geloven van en leven naar de leer van Christus en wordt bij het bestuur opgemerkt dat het door Christus is aangesteld.

Opvallend nu in zowel het staatsmodel als het verenigingsmodel zijn de centrale positie en de grote zeggenschap van de kerkelijke hiërarchie over de leden. De aard van het gezag is vooral formeel. Zijn positie en zeggenschap zijn bovendien theologisch stevig onderbouwd. Christus immers heeft het gezag ingesteld. Gezagsdragers stellen Hem tegenwoordig. De gelovigen worden als 'onderdanen' of als leden van een vereniging beschouwd. Zij hebben rechten en vooral plichten. Men wordt lid door het sacrament van het doopsel en blijft het voor het leven. Nuanceringen in het toebehoren zijn niet denkbaar. Onderlinge verhoudingen zijn sterk juridisch bepaald, universeel geldig en bij reglement - de Codex van 1917 als eerste wetboek voor de hele kerk - vastgelegd.

In een digitaliserende samenleving verliest dit verenigingsmodel steeds meer aan geloofwaardigheid. Het werkt niet langer en wordt gaandeweg vervangen door een netwerkmodel als alternatief. Volgens Liliane Voyé berust de vorming van netwerken op de vrije keuze van individuen. ${ }^{35} \mathrm{Zij}$ onttrekken zich daarmee aan groepen waar ze niet onderuit kunnen, zoals familie en religie. Het beginsel van groepsvorming in netwerken is dan ook affiniteit of een gedeeld probleem, belang of project. Terwijl voorgegeven instituties eigenlijk niet dulden dat men zich maar gedeeltelijk met hen identificeert of slechts in beperkte mate participeert, is gedeeltelijke identificatie en deelname, inclusief een nadruk op bepaalde aspecten, in netwerken een vanzelfsprekendheid. Het toebehoren varieert van kernlid tot sympathisant, van regelmatige bezoeker tot steunlid, terwijl ook een uitgesproken niet-sympathisant zich in de communicatie kan mengen. Partialiteit en pluraliteit zijn vanzelfsprekende kenmerken van een netwerkorganisatie. De omgang met de sociale media laat zien hoe vluchtig participatie aan een netwerk kan zijn, maar evenzeer hoe hardnekkig gelijkgezinden bijna als in een sekte bevestiging kunnen zoeken bij elkaar. Ze laten tevens zien hoe onuitwisbaar het digitale geheugen is en hoezeer ooit betoonde affiniteit iemand nagedragen kan worden. ${ }^{36}$

Zoals reeds opgemerkt, zijn netwerken polycentrisch van karakter. Dat geldt in ieder geval voor het gebruik. Achter mijn computer voel ik mijzelf een autonoom centrum van communicatie, onafhankelijk van een centrale sturing. Als zodanig ben ik een kruispunt van de netwerken waaraan ik zelf gekozen heb te participeren. Niettemin is deze autonomie in een digitale wereld relatief. Zonder de techScholen, Kweekscholen, Godsdienstcursussen en Jongens- en Meisjespatronaten (deel )1, 's-Hertogenbosch 1925, p. 27-28. Het cursief staat in de bron.

36 Vgl. H. Evers, 'Digitale media-ethiek', Collationes 2014, p. 65-67. 
nische mogelijkheden en zonder netwerkbeheer - in computertermen: facilitating en moderating - zou autonomie in het digitale verkeer niet mogelijk zijn. Een netwerk kent wel degelijk vormen van centrale sturing. Zij zijn alleen meer onzichtbaar dan in traditionele instituties.

\section{Uitdagingen voor kerkelijke leiding en kerkelijk beleid}

Een netwerkorganisatie zou inderdaad wel eens een belangrijk onderdeel kunnen worden van de sociale gestalte van het keuzekatholicisme. Voor welke uitdagingen stelt dit de leiding van de rooms-katholieke kerk en haar beleid? Ik ga kort in op een vijftal.

Een eerste uitdaging betreft de wijze van gezagsuitoefening. De autoritaire en niet-transparante leiderschapsstijl die kerkelijke gezagsdragers op alle niveaus zich konden veroorloven in het verenigingsmodel, is in een netwerkorganisatie niet langer geloofwaardig. Destijds kreeg een gezagsdrager op voorhand krediet. Een beroep op zijn formele autoriteit volstond om gelovigen tot volgzaamheid te bewegen. De inhoud van een beslissing was nauwelijks van belang. Kenmerkend voor dit type leiderschap, dat toen overigens breed in de samenleving voorkwam, is het streven naar beheersing en controle. De vraag is nu hoe kerkelijke gezagsdragers gestalte gaan geven aan hun leiderschap in een digitale netwerkorganisatie. Die vraag betreft wellicht minder hun liturgisch voorgaan, dat als digitale werkelijkheid vooralsnog een afgeleide blijft van het vieren realiter. Ze betreft vooral hun verkondigingstaak en bestuurlijke opdracht, in het bijzonder als er bestuurlijk of leerstellig grenzen in zicht komen. Drie trends tekenen zich mijns inziens af. In de eerste plaats zal de uitoefening van jurisdictie en leergezag - ze corresponderen in zekere zin met facilitating en moderating - meer verborgen en minder controlerend plaatsvinden. Veeleer zal kerkelijke leiders gevraagd worden te inspireren, mee te denken en te stimuleren. In de tweede plaats creëert de wereld van het internet een nieuw type gezag: het iconische of symbolische gezag van symboolfiguren in een netwerk. Zij zijn te herkennen aan hun vele 'volgers' en 'vrienden'. Cybergoeroes en cyberimams zijn voorbeelden ervan op het vlak van de religie. Ook paus Franciscus weet zich in dezen goed en belangeloos gericht op het evangelie te presenteren, terwijl zijn functie tegelijkertijd het hoogste leerstellig en jurisdictiegezag heeft. In de derde plaats is de sociale functie van het verbinden en verbonden houden van fundamenteel belang om inhoudelijk een boodschap te laten doordringen. Onder andere Twitter vervult deze functie in het vluchtige internetverkeer.

Er zullen zich overgangsperikelen voordoen. Sommige leiders opereren nog geheel en al in het verenigingsmodel en definiëren hun positie en bevoegdheden dienovereenkomstig. Andere leiders hebben al hun weg gevonden in een leiderschapsstijl die bij een netwerkorganisatie hoort. Dat kan tot conflicten leiden tussen leiders en leiders. Het geldt evenzeer voor degenen die zij leiden. Zij nemen immers eveneens zichzelf waar vanuit een van beide organisatiemodellen. Het kan tot gevolg hebben dat het besluit van een leider die naar volle overtuiging meent in 
het verenigingsmodel te opereren, door volgelingen, gewend in een netwerk te functioneren, wordt onthaald met een meewarig schouderophalen.

Een tweede uitdaging vormen de open grenzen van een netwerk. Het is niet langer op voorhand al duidelijk waar een deelnemer aan een netwerk in levensbeschouwelijk opzicht staat. De eenduidigheid van het lidmaatschap en de totale identificatie, hoewel niet uitgesloten, zijn niet langer normerend. Ieder die dat wenst en zich houdt aan de gedragscode, kan meespreken op digitale fora. Dat heeft tot gevolg dat de eigen traditie in andere mindsets verwoord zal moeten worden. Het kan leiden tot vervaging van grenzen tussen het katholicisme en andere religies of culturen en interreligieuze of interculturele hybriditeit. ${ }^{37}$ Medegelovigen zullen dergelijke grensoverschrijdingen niet altijd kunnen waarderen.

Een derde uitdaging betreft het feit dat netwerken op affiniteiten steunen. De deelname aan een netwerk kan allerlei variaties van loyaliteit of disloyaliteit vertonen. Zo is het ook mogelijk dat gelijkgezinden in een netwerk bij elkaar bevestiging zoeken. Wanneer dat geschiedt onder de noemer dat zij 'de ware katholieken' zijn, tart dit de rooms-katholieke invulling en vormgeving aan de waarde van katholiciteit. De vraag is immers of het desbetreffende netwerk van 'ware katholieken' representatief is. Vertegenwoordigt het de rooms-katholieke kerk als geheel of is het een deel dat pretendeert het geheel te zijn en zich ondertussen verre houdt van andere delen? In het ultramontaans massakatholicisme werd katholiciteit beschouwd als wereldwijd uniform ingevulde 'katholieke eenheid'. Het Eerste Vaticaans Concilie sprak in de dogmatische constitutie Dei Filius over die katholieke eenheid nog als een 'groot en blijvend geloofwaardigheidsmotief en een onweerlegbaar getuigenis' van de goddelijke zending van de kerk. ${ }^{38}$ Volgens het Tweede Vaticaans Concilie is katholiciteit veeleer een gave en opdracht tot communicatie en gemeenschapsvorming tussen onderling verschillende delen met elkaar en met het geheel. ${ }^{39}$ Terwijl in de tijd van dit laatste concilie pluriformiteit vooral verwees naar verscheidenheid op grond van geografische en historisch-culturele factoren, wordt het in een globaliserende kerkgemeenschap, versterkt door de snelheid van het digitale verkeer, steeds meer een verscheidenheid van affiniteiten. Dat brengt voor de kerkelijke leiding de bestuurlijke en beleidsmatige opgave met zich mee om ze voor elkaar open te doen staan, te verbinden en te doen communiceren.

De digitalisering roept als vierde uitdaging de vraag op of ook online Church, digitale vorming van een kerkgemeenschap, mogelijk is. ${ }^{40}$ De mogelijkheden van het internet niet te na gesproken, zal mijns inziens een digitale kerk slechts een hulpstructuur kunnen zijn. Zonder computer of digitale geletterdheid is men immers

Een voorbeeld is de ontmoeting tussen Christendom en hindoeïsme in de Khrist Bhakta Movement. Zie C.J. Kuttiyanikkal, Khrist Bhakta Movement: A Model for an Indian Church? Inculturation in the Area of Community Building (Tilburg Theological Studies 6), Münster 2014.

38 DH 3013.

39 Lumen gentium, nr. 13.

40 Witte 2014, p. 83-85; Onderzoeksgroep virtuele zingeving, Vrije Universiteit Amsterdam, 'De (on)mogelijkheid van de digitale kerk', zie www. handelingen. com/detailed -news/article/ de onmogelijkheid-van-de-digitale-kerk.htlm. Toegespitst op pastoraat: N. Sintobin, 'Internetpastoraat. Een ervaringsbericht', Collationes 2014, p. 95-102. 
uitgesloten van deelname. Dat past niet bij een geloofsgemeenschap die universeel wil zijn en die de armen een voorkeurspositie toekent. Bovendien hebben de sociale media grenzen die te maken hebben met de fysieke mogelijkheden van de mens. Zij spreken slechts de zintuigen van het zien en het horen aan. Zolang er geen wijwater en wierook uit de computer komen, doen andere zintuigen niet mee in een digitale ervaring van gemeenschap. Verbeeldingskracht zal moeten aanvullen wat het platte scherm te zien geeft. Zelfs als een website zich presenteert als een heilige ruimte, kan ik mij als deelnemer met behulp van een beeldscherm niet onttrekken aan de ditjes en datjes op het bureau waarop mijn computer staat. Helpt digitale kerkvorming om werkelijk kerk te zijn, dan is het geen probleem. Frustreert het om kerk te zijn, dan kunnen we beter niet doen alsof. Ook in dit opzicht moet het kerkelijk beleid zijn weg nog vinden.

Een laatste uitdaging betreft de vraag hoe de kerk zich op internet wil presenteren. Komt haar presentatie overeen met de waarden en de heilsboodschap die zij wil uitdragen of schiet zij er langs? Vorm en inhoud moeten dus kloppen. Een voorbeeld staat in een interview met dom Bernardus, abt van de Tilburgse trappistenabdij Koningshoeven. Abt en abdij begeven zich bewust in de virtuele wereld. 'Maar', zo zegt hij in het interview, 'in dat zoeken naar een goed gebruik van sociale media, staat me ook een aanbeveling van Benedictus voor de geest: doorbreek het stilzwijgen alleen als je spreken inhoud heeft. Het gevaar is vandaag groot dat je onnodig praat omdat je denkt dat heel de wereld moet weten dat je koffie aan het zetten bent. ${ }^{41}$

\section{Besluit}

In de overgang van het uniform en monocentrisch ultramontaans massakatholicisme naar een pluriform en veelledig keuzekatholicisme vindt een aantal ingrijpende transities in de rooms-katholieke kerk plaats. Het betreft in de eerste plaats het toenemend belang van het diocesane middenniveau in de kerk. Die gewichtstoename brengt in beginsel een nieuwe balans tussen het universele en het plaatselijke met zich mee en geeft ruimte aan een verscheidenheid van plaatselijke accenten in het geheel van de katholieke traditie. De overgang naar een keuzekatholicisme wordt versterkt door de digitalisering van de leefwereld. Het polycentrisme in het gebruik van de sociale media maakt het verenigingsmodel waarin de katholieke kerk over haar gestalte denkt, steeds minder overtuigend. Gaandeweg lijkt een netwerkmodel een alternatief te worden. Dat is een tweede belangrijke transitie. Ze stelt de kerk bestuurlijk en beleidsmatig voor belangrijke uitdagingen met betrekking tot haar leiderschapsstijl, lidmaatschap en participatie, katholiciteit, digitale gemeenschapsvorming en zelfpresentatie in de sociale media. 